\title{
Taxonomic Status of Micrococcus luteus (Schroeter 1872) Cohn 1872: Correla- tion Between Peptidoglycan Type and Genetic Compatibility
}

\author{
KARL H. SCHLEIFER, WESLEY E. KLOOS, and ANNE MOORE \\ Botanisches Institut, Universität München, 8 München 19, Germany and Department of Genetics, \\ North Carolina State University, Raleigh, North Carolina 27607
}

The type of peptidoglycan in the cell wall and the ability to transform auxotrophic mutants of Micrococcus luteus ATCC 27141 were determined for 55 strains of micrococci and related organisms. There exists a perfect correlation between these characteristics. Only strains containing the unique peptidoglycan of $M$. luteus (L-Lys-peptide subunit) can participate in the genetic exchange, and it is suggested that all such strains be placed in the species $M$. luteus.

The taxonomic status of the species Micrococcus luteus (Schroeter) Cohn is rather illdefined. In the minutes of the meeting of the International Subcommittee on Taxonomy of Staphylococci and Micrococci (2), it was stated that $M$. luteus is a broad-based species which is distinguished from other micrococci almost solely on a negative characteristic, namely, the absence of detectable acid from glucose when grown in the medium used for the standard $\mathrm{O} / \mathrm{F}$ test (15). All strains of $M$. luteus contain a high guanine plus cytosine (GC) ratio (66 to $72 \%$ ), and most of the strains fit into Micrococcus subgroup 1a of the classification of Rosypal et al. (11) or Micrococcus subgroup 7 of the scheme proposed by Baird-Parker (1). In this investigation it will be shown that $M$. luteus is defined by a unique peptidoglycan structure and the ability to produce transformants with M. luteus ATCC 27141.

\section{MATERIALS AND METHODS}

Bacterial strains. The strains of micrococci were obtained from different collections (Table 1).

Media. The organisms were maintained on yeast extract-glucose-sodium chloride-agar slants (14). Mass cultures were prepared in yeast extract-glucose-sodium chloride-broth under aerobic conditions (shaker) and harvested in the early stationary phase.

Methods. The methods used for preparing cell walls and determining the type of peptidoglycan were the same as described previously $(12,14)$. The procedure for transformation is also described in earlier publications (5-7).

\section{RESULTS}

Studies on the primary structure of the peptidoglycan of cell walls of $M$. luteus have revealed a unique peptidoglycan type $(4,13)$. The peptide subunits are connected in this case through bridges which are formed by a "head to tail linkage" of one to three peptide subunits. A fragment of the primary structure of such a peptidoglycan is depicted in Fig. 1. This peptidoglycan type will be abbreviated as L-Lys-peptide subunit according to the proposal of Schleifer and Kandler (Bacteriol. Rev., in press). Later studies by Campbell et al. (3) and Schleifer and Kandler (14) on the cell-wall composition of other micrococci have shown that the L-Lys-peptide subunit type of peptidoglycan is not restricted to a certain strain' of $M$. luteus but occurs among other strains. Meanwhile, we have extended our studies and have found a number of Micrococcus strains possessing this peptidoglycan type. Since this peptidoglycan type is so unique and to date has been found only in micrococci (Schleifer and Kandler, Bacteriol. Rev., in press), it is suggested that organisms containing this peptidoglycan type represent a defined taxon, $M$. luteus. However, this is not the only marker that distinguishes $M$. luteus. Studies on genetic transformation have shown that various strains of $M$. luteus can transform nutritional markers in crosses with the high-transformationfrequency strain $M$. luteus ISU (= ATCC 27141) (5, 7). In addition, various strains originally identified as belonging to species of 
TABLE 1. Ability of various members of the family Micrococcaceae to transform Micrococcus luteus ATCC 27141 reference mutants in comparison with their peptidoglycan types

\begin{tabular}{|c|c|c|c|c|}
\hline Received as & Strain & $\begin{array}{l}\text { Ability to } \\
\text { transform } \\
\text { M. luteus }\end{array}$ & $\begin{array}{c}\text { Peptidoglycan } \\
\text { type }^{b}\end{array}$ & $\begin{array}{l}\text { Identified } \\
\text { as }\end{array}$ \\
\hline Micrococcus luteus & $\mathrm{CCM}^{c} 166$ & + & L-Lys-peptide subunit & Micrococcus luteus \\
\hline$M$. luteus $\ldots \ldots \ldots \ldots \ldots \ldots$ & CCM $169\left(\mathrm{ATCC}^{d} 4698\right)$ & + & L-Lys-peptide subunit & M. luteus \\
\hline$M$. luteus $\ldots \ldots \ldots \ldots \ldots \ldots$ & CCM 309 & + & L-Lys-peptide subunit & M. luteus \\
\hline M. luteus . . . . . . . . . . & CCM 331 & + & L-Lys-peptide subunit & M. luteus \\
\hline M. luteus . . & CCM 355 & + & L-Lys-peptide subunit & M. luteus \\
\hline$\ldots \ldots \ldots \ldots \ldots$ & CCM 370 & + & L-Lys-peptide subunit & M. luteus \\
\hline$\ldots \ldots \ldots$ & CCM 409 & + & L-Lys-peptide subunit & M. luteus \\
\hline M. luteus $\ldots \ldots \ldots \ldots \ldots \ldots$ & CCM 622 & + & L-Lys-peptide subunit & M. luteus \\
\hline M. luteus . . . . . . . . . & CCM 851 & + & L-Lys-peptide subunit & M. ıuteus \\
\hline M. luteus . . . . . . . . . & CCM 853 & + & L-Lys-peptide subunit & M. luteus \\
\hline$M$. luteus $\ldots \ldots \ldots \ldots \ldots$ & CCM 1335 & + & L-Lys-peptide subunit & M. luteus \\
\hline$\ldots \ldots \ldots \ldots \ldots$ & CCM 1569 & + & L-Lys-peptide subunit & M. ıuteus \\
\hline M. luteus . . . . . . . . . & CCM 1674 & + & L-Lys-peptide subunit & M. luteus \\
\hline M. lysodeikticus . . . . . . . . & ATCC 12698 & + & L-Lys-peptide subunit & M. ıuteus \\
\hline M. flavus $\ldots \ldots \ldots \ldots \ldots \ldots$ & ATCC 400 & + & L-Lys-peptide subunit & M. luteus \\
\hline M. flavus ... & ATCC 10240 & + & L-Lys-peptide subunit & M. luteus \\
\hline M. flavocyaneus . ........... & ATCC 8673 & + & L-Lys-peptide subunit & M. ıteus \\
\hline M. sodonensis . . . . . . . . & ATCC 11880 & + & L-Lys-peptide subunit & M. luteus \\
\hline M. ureae $\ldots \ldots \ldots \ldots \ldots$ & CCM 840 & + & L-Lys-peptide subunit & M. luteus \\
\hline Sarcina flava. & ATCC 147 & + & L-Lys-peptide subunit & M. luteus \\
\hline S. flava ....... & ATCC 540 & + & L-Lys-peptide subunit & M. luteus \\
\hline S. Iutea $\ldots \ldots \ldots \ldots \ldots \ldots$ & ATCC 272 & + & L-Lys-peptide subunit & M. luteus \\
\hline S. Iutea $\ldots \ldots \ldots \ldots \ldots \ldots$ & ATCC 382 & + & L-Lys-peptide subunit & M. luteus \\
\hline S. Iutea $\ldots \ldots \ldots \ldots \ldots \ldots$ & ATCC 9622 & + & L-Lys-peptide subunit & M. luteus \\
\hline S. lutea & ATCC 15220 & + & L-Lys-peptide subunit & M. luteus \\
\hline S. subflava $\ldots \ldots \ldots \ldots \ldots$ & ATCC 7468 & + & L-Lys-peptide subunit & M. luteus \\
\hline Mycococcus luteus. & CCM 1747 & + & L-Lys-peptide subunit & M. luteus \\
\hline Mycococcus luteus . . . . . . . . & BKM-B $963^{e}$ & + & L-Lys-peptide subunit & M. luteus \\
\hline Staphylococcus afermentans ..... & ATCC 15307 & + & L-Lys-peptide subunit & M. luteus \\
\hline$M$. citreus . . . . . . . . . & ATCC 395 & - & L-Lys-Gly-L-Glu & M. species \\
\hline M. conglomeratus . ......... & CCM 2134 & - & $m$-Dpm-D-Glu 2 & Uncertain \\
\hline M. conglomeratus $\ldots \ldots \ldots \ldots$ & CCM 2135 & - & $m-\mathrm{Dpm}-\mathrm{D}-\mathrm{Glu}_{2}$ & Uncertain \\
\hline$M$. conglomeratus $\ldots \ldots \ldots \ldots$ & ATCC 401 & - & L-Lys-L-Ala $3-4$ & M. varians \\
\hline M. luteus $\ldots \ldots \ldots \ldots \ldots$ & ATCC 398 & - & L-Lys-Gly-L-Glu & M. species \\
\hline M. luteus $\ldots \ldots \ldots \ldots \ldots$ & CCM 2137 & - & $m$-Dpm-D-Glu 2 & Uncertain \\
\hline M. luteus . . . . & CCM 2253 & - & L-Lys-L-Ala $3-4$ & M. species \\
\hline M. varians $\ldots \ldots \ldots \ldots \ldots \ldots$ & CCM 268 & - & L-Lys-L-Ala & M. varians \\
\hline $\boldsymbol{M}$. varians $\ldots \ldots \ldots \ldots \ldots$ & CCM 418 & - & L-Lys-L-Ala & M. varians \\
\hline $\boldsymbol{M}$. varians $\ldots \ldots \ldots \ldots \ldots$ & CCM 1395 & - & L-Lys-L-Ala $3-4$ & M. varians \\
\hline M. varians . . . . . & CCM 2139 & - & L-Lys-L-Ala $3-4$ & M. varians \\
\hline$M$. varians $\ldots \ldots \ldots \ldots \ldots$ & CCM 2141 & - & L-Lys-L-Ala $3-4$ & M. varians \\
\hline$M$. varians $\ldots \ldots \ldots \ldots \ldots$ & CCM 2189 & - & L-Lys-L-Ala $3-4$ & M. varians \\
\hline$M$. varians $\ldots \ldots \ldots \ldots \ldots$ & ATCC 399 & - & L-Lys-L-Ala $3-4$ & M. varians \\
\hline$M$. roseus $\ldots \ldots \ldots \ldots \ldots$ & ATCC 186 & - & L-Lys-L-Ala & $M$. roseus \\
\hline M. roseus . . . . . . . . . & ATCC 397 & - & L-Lys-L-Ala $3-4$ & $M$. roseus \\
\hline$M$. roseus . . . . . . . . . . . & ATCC 412 & - & L-Lys-L-Ala $3-4$ & M. roseus \\
\hline$M$. roseus . . . . . . . . . . & ATCC 416 & - & L-Lys-L-Ala $3-4$ & $M$. roseus \\
\hline$M$. roseus . . . . . & ATCC 516 & - & L-Lys-L-Ala $3-4$ & $M$. roseus \\
\hline$M$. roseus . . . . . & ATCC 9815 & - & L-Lys-L-Ala $3-4$ & M. roseus \\
\hline$M$. radiodurans $\ldots \ldots \ldots \ldots$ & ATCC 13939 & - & $\mathrm{L}-\mathrm{Orn}-\mathrm{Gly}_{2-3}$ & Uncertain \\
\hline Sarcina aurantiaca ........ & ATCC 146 & - & L-Lys-L-Ala $3-4$ & Micrococcus species \\
\hline S. ervthromyxa .......... & ATCC 187 & - & L-Lys-L-Ala $3-4$ & Micrococcus species \\
\hline S.lutea $\ldots \ldots \ldots \ldots \ldots$ & ATCC $533^{8}$ & - & L-Lys-L-Ala $3-4$ & M. varians \\
\hline S. ureae $\ldots \ldots \ldots \ldots \ldots \ldots$ & ATCC 6473 & - & L-Lys-Gly-D-Glu & Sporosarcina ureae \\
\hline
\end{tabular}

${ }^{a}$ Symbols : +, DNA from organism was capable of transforming $\boldsymbol{M}$. luteus ATCC 27141; -, no transformation of $\boldsymbol{M}$. luteus.

${ }^{b} \mathrm{Abbreviation}$ of the peptidoglycan types according to Schleifer and Kandler (Bacteriol. Rev., in press).

${ }^{c}$ CCM, Czechoslovak Collection of Microorganisms, Brno, CSSR.

${ }^{d}$ ATCC, American Type Culture Collection, Rockville, Md.

e Obtained from Tsukamura, Chuba Chest Hospital, Obu, Aichi-Ken 474, Japan.

The peptidoglycan of strain ATCC 397 was inadvertently presented as L-Lys-peptide subunit in a previous paper (13).

${ }^{8} S$. lutea ATCC 533 cannot serve as a donor in transformation as previously stated; only $S$. lutea FD (Fort Detrick) 533 can serve as a donor. 


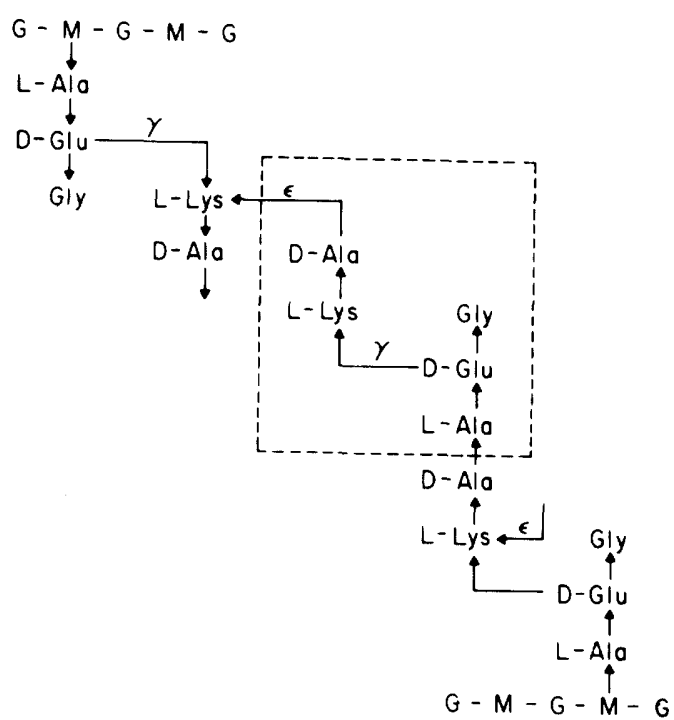

FIG. 1. Fragment of the primary structure of the peptidoglycan of Micrococcus luteus. The cross-linkage bridge is marked by a dashed frame. In this case the cross-linkage bridge consists of only one peptide subunit, but up to three peptide subunits can be involved in forming the cross-linkage bridge (4). A corresponding amount of muramic acid residues (up to $50 \%$ ) shows an unsubstituted carboxyl group. $M$, $N$-acetylmuramic acid; $G, N$-acetylglucosamine. $\gamma$, $\gamma$-carboxyl group of glutamic acid involved in the peptide linkage; $\epsilon, \epsilon$-amino group of lysine involved in the peptide linkage.

the genera Micrococcus, Sarcina, and Staphylococcus were able to transform tryptophan, histidine, and adenine auxotrophs of $M$. luteus ATCC 27141 to prototrophy with an efficiency equal to that of homologous crosses (6). Since nutritional markers are usually transformed only among very closely related organisms, it was suggested by Kloos (6) that all strains capable of transforming $M$. luteus ATCC 27141 are members of a single species, $M$. luteus. Thus, independent studies on the peptidoglycan structure and the genetic compatibility of Micrococcus species have indicated that the species $M$. luteus can be defined by two characteristics: the ability to transform $M$. luteus ATCC 27141 reference mutants with high efficiency and the presence of the L-Lys-peptide subunit peptidoglycan type in the cell wall. Unfortunately, both properties have been determined for only a few strains simultaneously. Therefore we have extended our studies on the genetic exchange between $M$. luteus ATCC 27141 reference mutants and various strains of micrococci and compared the results with their peptidoglycan type (Table 1).

\section{DISCUSSION}

There is good correlation between the peptidoglycan type and genetic compatibility. All strains containing L-Lys-peptide subunit peptidoglycan are capable of transforming auxotrophic mutants of $M$. luteus ATCC 27141 with high efficiency. Thus, in our opinion all strains possessing these two properties should be identified as M. luteus. It is sufficient, however, to determine either the peptidoglycan type or capability of genetic exchange for the identification of $M$. luteus, since these two properties are perfectly correlated. On the basis of the foregoing, a great number of strains have been incorrectly identified (Table 1), particularly strains belonging to Sarcina lutea, S. subflava, Micrococcus flavus, $M$. flavocyaneus, $M$. flavoroseus, $M$. ureae, or $M$. sodonensis. Moreover, strains identified as belonging to Mycoccus luteus Krasill'nikov (9) behave as typical strains of Micrococcus luteus. Our results are in accord with those obtained in studies on the hydrocarbon composition of certain Micrococcus strains $(10,16)$. The hydrocarbon patterns of the $M$. luteus strains studied thus far are different from those of other micrococci (10). Our results are also in good agreement with the studies by Kocur et al. (8). Of the 30 strains which we classified as $M$. luteus, 21 strains (CCM 169 [the neotype strain (8)], 247, 309, $331,409,622,851,853,1335,1569$, and 1674; ATCC 147, 272, 382, 400, 540, 7468, $10240,11880,12698$, and 15220) were also studied by these authors ( 8$)$ and were identified as $M$. luteus.

\section{LITERATURE CITED}

1. Baird-Parker, A. C. 1965. The classification of staphylococci and micrococci from world-wide sources. J. Gen. Microbiol. 38:363-387.

2. Baird-Parker, A. C. 1971. Minutes of the meeting of the Sub-committee on Taxonomy of Staphylococci and Micrococci, 3 April 1968. Int. J. Syst. Bacteriol. 21:161-163

3. Campbell, J. N., M. Leyh-Bouille, and J. M. Ghuysen. 1969. Characterization of the Micrococcus lysodeikticus type of peptidoglycan in walls of other micrococcaceae. Biochemistry 8:193-200.

4. Ghuysen, J. M., E. Bricas, M. Lache, and M. Leyh-Bouille. 1968. Structure of the cell walls of Micrococcus lysodeikticus. III. Isolation of a new peptide dimer, $\mathrm{N}^{\alpha}$ - [L-alanyl- $\gamma$ - $(\alpha-\mathrm{D}$-glutamyl-glycine)] -L-ly syl-D- alanyl- $\mathrm{N}^{\alpha}$ - [L- alanyl- $\gamma-(\alpha$-Dglu tamyl-glycine)]-L-lysyl-D-alanine. Biochemistry $7: 1450-1460$. 
5. Kloos, W. E. 1969. Factors affecting transformation of Micrococcus lysodeikticus. J. Bacteriol. 98: 1397-1399.

6. Kloos, W. E. 1969. Transformation of Micrococcus lysodeikticus by various members of the family Micrococcaceae. J. Gen. Microbiol. 59:247-255.

7. Kloos, W. E., and L. M. Schultes. 1969. Transformation in Micrococcus lysodeikticus. J. Gen. Microbiol. 55:307-317.

8.. Kocúr, M., Z. Páčová, and T. Martinec. 1972. Taxonomic status of Micrococcus luteus (Schroeter 1872) Cohn 1872, and designation of the neotype strain. Int. J. Syst. Bacteriol. 22:218 223.

9. Krasill'nikov, N. A. 1959. Diagnostik der Bakterien und Actinomyceten. Gustav Fischer Verlag, Jena.

10. Morrison, S. J., T. G. Tornabene, and W. E. Kloos. 1971. Neutral lipids in the study of relationships of members of the family Micrococcaceae. J. Bacteriol. 108:353-358.

11. Rosypal, S., A. Rosypalova, and J. Horejs. 1966.
The classification of micrococci and staphylococci based on their DNA base composition and Adansonian analysis. J. Gen. Microbiol. 44:281292.

12. Schleifer, K. H., and O. Kandler. 1967. Zur chemischen Zusammensetzung der Zellwand der Streptokokken I. Die Aminosäure-sequenz des Mureins von Str. thermophilus and Str. faecalis. Arch. Mikrobiol. 57:335-364.

13. Schleifer, K. H., and O. Kandler. 1967. Micrococcus lysodeikticus: a new type of cross-linkage of the murein. Biochem. Biophys. Res. Commun. 28:965-972.

14. Schleifer, K. H., and O. Kandler. 1970. Amino acid sequence of the murein of Planococcus and other Micrococcaceae. J. Bacteriol. 103:387-392.

15. Subcommittee on Taxonomy of Staphylococci and Micrococci. 1965. Recommendation. Int. Bull. Bacteriol. Nomencl. Taxon. 15:109-110.

16. Tornabene, T. G., S. J. Morrison, and W. E. Kloos. 1970. Aliphatic hydrocarbon contents of various members of the family Micrococcaceae. Lipids 5:929-937. 